\title{
The Importance of Intrinsic Factors in Keeping Employees Motivated: The Difference between Public and Private Sectors
}

\section{Abdul Kadir Othman \& Ali AlKahtani}

To Link this Article: http://dx.doi.org/10.6007/IJARBSS/v11-i11/11539

DOI:10.6007/IJARBSS/v11-i11/11539

Received: 05 September 2021, Revised: 07 October 2021, Accepted: 28 October 2021

Published Online: 18 November 2021

In-Text Citation: (Othman \& AlKahtani, 2021)

To Cite this Article: Othman, A. K., \& AlKahtani, A. (2021). The Importance of Intrinsic Factors in Keeping Employees Motivated: The Difference between Public and Private Sectors. International Journal of Academic Research in Business and Social Sciences, 11(11), 2140-2155.

\section{Copyright: (c) 2021 The Author(s)}

Published by Human Resource Management Academic Research Society (www.hrmars.com) This article is published under the Creative Commons Attribution (CC BY 4.0) license. Anyone may reproduce, distribute, translate and create derivative works of this article (for both commercial and non0-commercial purposes), subject to full attribution to the original publication and authors. The full terms of this license may be seen at: http://creativecommons.org/licences/by/4.0/legalcode

$$
\text { Vol. 11, No. 11, 2021, Pg. } 2140 \text { - } 2155
$$

Full Terms \& Conditions of access and use can be found at http://hrmars.com/index.php/pages/detail/publication-ethics 


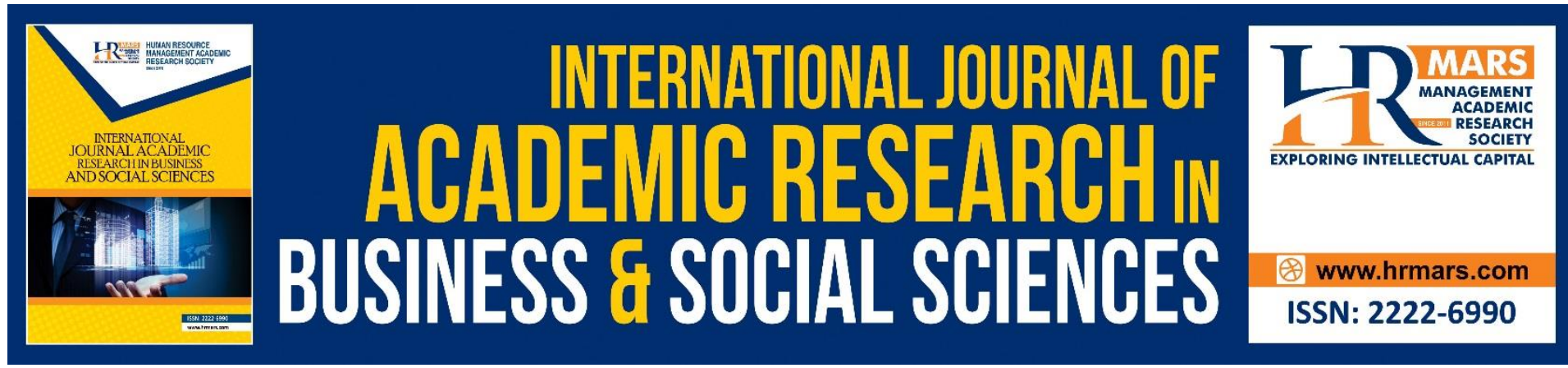

\title{
The Importance of Intrinsic Factors in Keeping Employees Motivated: The Difference between Public and Private Sectors
}

\author{
Abdul Kadir Othman ${ }^{1} \&$ Ali AlKahtani ${ }^{2}$ \\ ${ }^{1}$ Institute of Business Excellence Universiti Teknologi MARA40450 Shah Alam, Selangor, \\ Malaysia, ${ }^{2}$ Vice President of Academic Affairs Faculty of Economics and Administration King \\ Abdul Aziz University P.O. Box 80201, Jeddah, Sausi Arabia \\ Email: abdkadir@uitm.edu.my, ealkahTAN@kau.edu.sa
}

\begin{abstract}
The topic of motivation has been researched over the years and it will continue in the future due to its significant impact to the individual employee and the organization as a whole. Although there are numerous established models of motivation, a specific study on a specific organization is required due to organizational cultural and attributive differences. This study was undertaken to investigate the intrinsic factors that motivate service employees to do their job. A total of 113 respondents participated in the survey questionnaire that was distributed using online means to various organizations; public and private. Factor analysis confirmed the existence of the studied factors and all other analysis results indicate the usability of the data. The results indicate that out of six intrinsic factors, four factors are significant to motivate service employees to do their job. The significant factors are advancement, recognition, growth, and achievement while the non-significant factors are the work itself and responsibility. Types of organization did not moderate the relationship between the predictor variables and the outcome variable. The implications of the study are discussed.
\end{abstract}

Keywords: Intrinsic Motivation, Advancement, Recognition, Growth, Achievement Work Itself, Responsibility

\section{Introduction}

Employees' motivation is critical in ensuring that the organization maintains high performance especially in service organizations. Service organizations are unique as the services are intangibles, mostly involve in high interaction with customers (either using human or machine interaction), and they are difficult to be quantified. The are a lot of service models proposed by various theorists that explain the characteristics of services (e.g. Silvestro et al., 1992; Jaakkola, et al., 2017). According to Silvestro et al (1992), service can be categorized into three; professional service, service shop and mass service, based on the characteristics of service including high/low contact time, high/ low customization, high/low discretion, people/equipment focus, front/back office oriented, and process/product oriented. 
Different from organizations that offer products to customers, service organizations offer services that are difficult to be measured and quantified. They fall under professional service or service shop group as they are categorized as having high/moderate contact time, high/moderate customization, high/moderate discretion, mixed people/equipment focus, mixed front/back office oriented, and process oriented (Jaakkola, et al., 2017). Sometimes, the employees are in the dark of how they are doing in delivering the service. This may demotivate them in performing their tasks. As most management theorists and practitioners believe and preach, feedback from the job (including the success of service delivery) is important to motivate the employees (Larivière, et al., 2017).

Service organizations can be categorized into two types; public and private service organizations (McCarthy et al., 2019). Government agencies, public hospitals, public universities, and others are considered as public service organizations, while private universities, transportation services, telecommunication service, private hospitals and others fall under the private service type. The objectives of public and private organizations are distinct as public service is meant to provide better support for living for free of charge (although the public have to pay taxes). Private organizations, on the other hand, offer service at certain price as consumers have to pay for the service once delivered.

Due to different nature of service, employees in private service organizations are well aware of their performance and this will make them more motivated to provide better services in future. However, employees in the public service organizations, are less informed regarding their service performance because of lack of indicators to measure the service performance unless the organizations take a proactive approach to assess the customers' level of satisfaction during the service delivery. Studies pertaining to the moderating role of public and private service type are limited (Christensen et al., 2017; Osborne, 2018), thus the present study was conducted to address the gap in literature and provide some insights into the human resource field.

This paper is meant to investigate the role of public/private service type as the moderator in affecting the relationship between intrinsic factors and employee motivation. The paper is organized as follows: the background of the study, the review of literature, the methodology of the study, the findings and discussion and conclusion. Implications of the study will also be discussed in the concluding section.

\section{Literature Review \\ Employee Motivation}

The term motivation was originated from the Latin word for movement (movere). Based on this concept, Atkinson defines motivation as "the contemporary (immediate) influence on direction, vigor, and persistence of action" (1964: 2). Many authors have developed theories and models to predict motivation among employees such as Maslow's Hierarchy of Needs theory, McClelland Motivation theory, Herzberg's Motivation-Hygiene theory, Equity theory and others. Since this paper is focusing on the intrinsic motivation factors, the most relevant theory is Herzberg's Motivation-Hygiene theory but the focus will be on the motivators alone.

Herzberg (1956) proposed the two factor theory of motivation that comprises motivators and hygiene factors. Motivators are job-related factors that include achievement, recognition, the 
work itself, responsibility, advancement, and growth. The presence of motivators will make employees work harder. But, the absence of these factors will move employees to neutral states. Hygiene factors are the surrounding job factors that include company policies, supervision, relationships, work conditions, remuneration, salary and security. The absence of these factors will lead employees to work less hard but the presence of these factors will lead employees to be neutral.

\section{The Work Itself}

Employees do their job daily for an extended period of time. The job itself must be interesting, rich, and provide sufficient levels of challenges to keep them motivated. Studies have provided enough evidence showing the strong connection between the work itself and employee motivation (e.g. Rodrigues, 2018). A study found that intrinsic motivation in general is able to alleviate job-related fatigue (Liu, Fan, Fu, \& Liu, 2018). Dull and routine work will make employees to be less motivated to execute their job role and responsibilities (Van Hooff, \& Van Hooft, 2017; Van Tuin et al., 2020). Based on the discussion, it is hypothesized that the work itself will influence employee motivation.

\section{Advancement}

Job advancement shows that employees have been doing very well and deserves job promotion since every employee always looks for better job positions when his basic needs have been met. Therefore, promotion opportunities should exist for the employee. Studies have shown the importance of this factor in motivating employees. Asaari et al (2019) in their study on salary, promotion, and recognition toward work motivation among government trade agency employees confirmed that promotion leads to motivation. Another study by Haryono et al (2020) found that job promotion both directly and indirectly shows a positive and significant effect on employee motivation. Based on the discussion, it is hypothesized that advancement will influence employee motivation.

\section{Recognition}

Recognition refers to appreciation received by employees after they have accomplished the assigned job. To ensure employees' motivation, employers must provide them with praise and recognition of their successes. This recognition should be given by their superiors and peers. Studies have provided evidence to support the relationship between recognition and motivation. Asaari et al (2019) when studying government trade agency employees' motivation found that recognition has a positive relationship with motivation. Other studies also found similar results (e.g. Grant, et al., 2018; Rahim et al., 2017). Therefore, it is hypothesized that recognition will influence employee motivation.

\section{Growth}

Growth concerns the lateral movement or change from the current state to a better state. It means that the job should provide employees with the opportunity to learn new skills, which can be learned through either on the job or more formal training. More studies found supporting evidence that growth opportunity will lead to employee motivation. A study in Vietnam among civil servants found that career development leads to employee motivation (Linh, 2019). Another study by Mani, and Mishra (2020); Rhew et al (2018) found that growth mindset influences motivation in general. Therefore, it is hypothesized that growth opportunity will influence employee motivation. 


\section{Achievement}

An employee must feel a sense of achievement from doing the job before he/she becomes motivated. Doing something challenging but worthwhile will create a feeling of pride. A study found significant influence of achievement motivation behavior on work performance (Werdhiastutie et al., 2020). Another study involving a total of 400 Gen $Y$ from top 10 Malaysian GLCs within Klang Valley revealed that there was a strong relationship between achievement and job commitment (Mohamed \& Puteh, 2018). Another study also supports the connection between the two variables. Asaari et al (2019) discovered that achievement has a positive relationship with motivation among government servants in Malaysia. Therefore, it can be summarized that achievement will influence employee motivation.

\section{Responsibility}

Employees should have a sense of ownership when doing their work. They should hold themselves responsible for job completion. A study among excellent school teachers found that responsibility is one of the intrinsic factors scored highly by them (Amzat et al., 2017) and this will lead to heightened motivation level (Abdelmotaleb, 2020). A study among the TVET instructors found that intrinsic motivation including responsibility (among others) contributes to instructors job satisfaction (Omar et al., 2018). Ravesangar and Muthuveloo (2019) also discover a similar link between intrinsic motivation factors (including responsibility) and job performance among employees in banking sector. Therefore, it can be summarized that job responsibility will influence employee motivation.

\section{The Moderating Role of Organization Types on the Relationship between Intrinsic Motivation Factors}

Public and private organizations have different objectives for existence. Public service organizations are established to serve the public by providing the fundamental services in order to improve public well-being. Private organizations like any other businesses exist to satisfy the needs of the stakeholders (e.g. the investors and shareholders). The former provides service free of charge although the public have to pay taxes but the latter offers services at certain prices. The public have to pay for the services when delivered. The performance of public organizations is measured by the ability of the organizations to meet the needs of the public but the performance of private organizations are evaluated on profitability of the businesses.

Employees in public organizations are assigned with certain non-financial KPIs but most employees in private organizations are assessed using financial KPIs. They have targets to be met in each month and throughout the year. Due to the different nature of work, performance target and work culture, it is expected that the factors that motivate employees from these two types of organization are different. In public service organizations, these intrinsic factors that include the work itself, advancement, recognition, growth, achievement, and responsibility are expected to be highly correlated with motivation as compared to those in private organizations, where these factors are expected to be weakly correlated with motivation.

\section{Methodology}

The present correlational research was undertaken to examine the role of intrinsic factors in influencing employee motivation. Types of organization are included as a moderating factor 
that is expected to moderate the relationship between the predictors and the outcome variable. The study was conducted among service employees working in service organizations that include higher learning institutions, small medium enterprises, banks and various government agencies located in Lembah Klang. Quota sampling technique (Iliyasu \& Etikan, 2021) was applied to select the respondents working in service organizations; half of the samples would be collected from public organizations and another half would be collected from private organizations.

The research instrument for the present study was developed by the author by referring to the existing theories and studies related to motivation. Based on the construct definitions and dimensions, the items in the questionnaire were carefully selected so that they would accurately measure the intended variables. The items were then validated by experts in management studies. The instrument was later pilot tested among the master students to ensure that each item was clearly understood and any comments and suggestions received were used to improve it before it could be utilized to collect the required data for the study. A total of 150 sets of questionnaire were distributed via online platforms and the response received was 113 , making the response rate of $75.33 \%$.

Data were analyzed using SPSS version 23 for descriptive statistics, factor analysis, reliability, correlation and moderated multiple regression analyses. The following sections will discuss the analysis used and the findings of the study.

\section{Data Analysis and Findings}

Descriptive analysis was performed to examine the distribution of the respondents. From the results, $68.1 \%$ of the respondents are male and $31.9 \%$ are female. Regarding the age distribution, $14 \%$ were aged between $21-35$ years old, $73.7 \%$ were aged between $36-50$ years old, $11.4 \%$ were aged between $51-65$ years old, only one respondent was more than 65 years old. The statistics indicate that they represent the distribution of the workforce in the country. Pertaining to the sector of employment, $43.9 \%$ of respondents worked in the private sector, $49.1 \%$ worked in the public sector and $7 \%$ worked in both sectors. These findings indicate the suitability of data to be used to analyze the moderating effect of the organization types.

Concerning the period that the company has been involved in business, $10.5 \%$ has been in operation for less than 5 years, $14 \%$ has been in business between 5 and 10 years, $30.7 \%$ has been in operation between 10 and 20 years, and $44.7 \%$ has been in business for more that 20 years. Regarding the number of employees in the organization, $24.6 \%$ worked in the company that employ 1 to 20 staff, $11.4 \%$ said that their organization has 21 to 50 staff, $12.3 \%$ said that their company has 50 to 100 employees. 7\% worked with between 101 and 200 colleagues and $44.7 \%$ had more than 200 co-workers working with them. The size of the organization is significant enough to be studied.

Concerning job position, respondents held various positions in the organization, $1.8 \%$ respondents were the chief executive officer, $5.3 \%$ respondents were the managing director, $21.9 \%$ were the manager in their organizations, $4.4 . \%$ were engineers, $14 \%$ were supervisors and $52.6 \%$ were holding various positions in their respective organizations. Looking at the length of service of the respondents in their respective organizations, $24.6 \%$ of them had $1-5$ years of experience, $14.9 \%$ had $5-10$ years of working experience, $33.3 \%$ of them had been 
working between 10 and 20 years, and $27.2 \%$ of respondents had over 20 years of working experience. Pertaining to the educational qualification the respondents had, $21.1 \%$ of respondents had Certificate, $27.2 \%$ had Diploma, 32.5\% had BSc Degree / BSc, $12.3 \%$ had Masters, and $7 \%$ had PhD / Doctorate. The respondents have the right education levels to provide usable input to the study.

Table 1: Respondents' Profile

\begin{tabular}{|c|c|c|c|}
\hline Variables & Description & Frequencies & Percentages \\
\hline \multirow[t]{2}{*}{ Gender } & Male & 77 & 68.1 \\
\hline & Female & 36 & 31.9 \\
\hline \multirow[t]{4}{*}{ Age } & $21-35$ years & 16 & 14.0 \\
\hline & $36-50$ years & 84 & 73.7 \\
\hline & $51-65$ years & 13 & 11.4 \\
\hline & $>65$ years & 1 & 0.9 \\
\hline \multirow[t]{3}{*}{ Sector } & Private & 50 & 43.9 \\
\hline & Public & 56 & 49.1 \\
\hline & Both & 8 & 7.0 \\
\hline \multirow[t]{4}{*}{$\begin{array}{l}\text { Period in } \\
\text { employment }\end{array}$} & $0-5$ years & 12 & 10.5 \\
\hline & $5-10$ years & 16 & 14.0 \\
\hline & 10 years -20 years & 35 & 30.7 \\
\hline & $>20$ years & 51 & 44.7 \\
\hline \multirow[t]{5}{*}{ No of Employees } & $1-20$ & 28 & 24.6 \\
\hline & $21-50$ & 13 & 11.4 \\
\hline & $50-100$ & 14 & 12.3 \\
\hline & $101-200$ & 8 & 7.0 \\
\hline & $>200$ & 51 & 44.7 \\
\hline \multirow[t]{6}{*}{ Job Position } & Chief Executive Officer & 2 & 1.8 \\
\hline & Managing Director & 6 & 5.3 \\
\hline & Manager & 25 & 21.9 \\
\hline & Engineer & 5 & 4.4 \\
\hline & Supervisor & 16 & 14.0 \\
\hline & Others & 60 & 52.6 \\
\hline \multirow[t]{4}{*}{ Length of Service } & $1-5$ years & 28 & 24.6 \\
\hline & $5-10$ years & 17 & 14.9 \\
\hline & $10-20$ years & 38 & 33.3 \\
\hline & Over 20 years & 31 & 27.2 \\
\hline \multirow[t]{5}{*}{ Education } & Certificate & 24 & 21.1 \\
\hline & Diploma & 31 & 27.2 \\
\hline & BSc Degree / BSc & 37 & 32.5 \\
\hline & Masters & 14 & 12.3 \\
\hline & PhD / Doctorate & 8 & 7.0 \\
\hline
\end{tabular}


Table 2: Results of Factor Analysis for the Dependent Variable

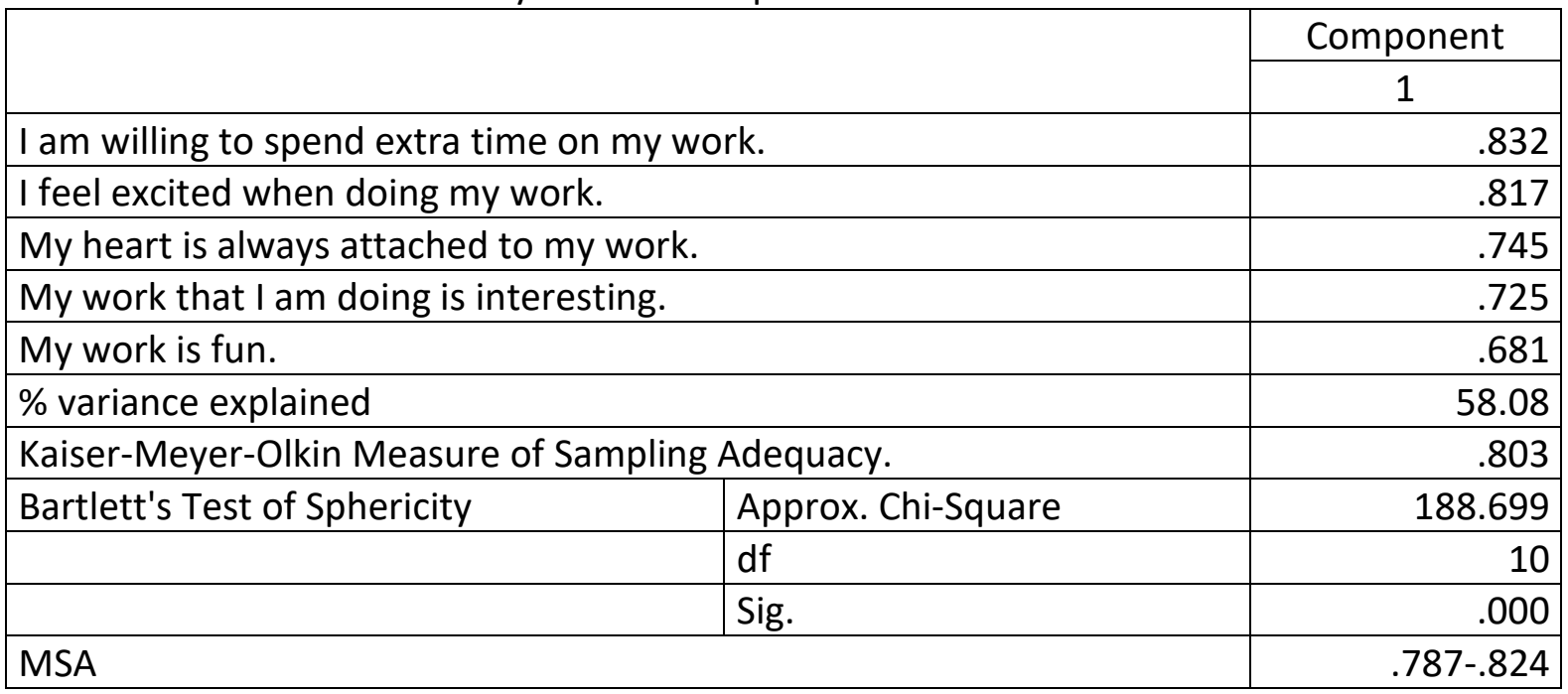

Extraction method: Principle Component Analysis

Factor analysis is performed to determine the dimensionality of the construct so that the items measuring the construct truly and adequately assess the construct. To conduct factor analysis for each type of variables; independent variables and the dependent variable, two series of factor analysis were conducted. For the dependent variable; motivation, a principle component factor analysis with varimax rotation was utilized. The KMO value of 0.803 exceeds the threshold value of 0.6 and it is significant. The findings indicate the correlation matrix is sufficient to proceed with the analysis. The MSA values range from .787 to .824 . The five items load under one component with loadings ranging from .681 to .832 . Therefore, the dimensionality of the variable was confirmed and it was ready for subsequent analysis. 
Table 3: Results of Factor Analysis for the Independent Variables

\begin{tabular}{|c|c|c|c|c|c|c|}
\hline & \multicolumn{6}{|c|}{ Component } \\
\hline & 1 & 2 & 3 & 4 & 5 & 6 \\
\hline $\begin{array}{l}\text { The work that I am doing allows me to know my } \\
\text { strengths and weaknesses. }\end{array}$ & .790 & & & & & \\
\hline The work that I am doing increases my self-esteem. & .737 & & & & & \\
\hline The work that I am doing is challenging. & .731 & & & & & \\
\hline $\begin{array}{l}\text { The work that I am doing allows me to use my skills } \\
\text { and abilities. }\end{array}$ & .730 & & & & & \\
\hline The work that I am doing enhances my self-worth. & .694 & & & & & \\
\hline $\begin{array}{l}\text { My work provides me with opportunities for career } \\
\text { advancement. }\end{array}$ & & .835 & & & & \\
\hline My work clarifies my career path. & & .802 & & & & \\
\hline $\begin{array}{l}\text { My work opens up opportunities for me to achieve } \\
\text { my career goal. }\end{array}$ & & .799 & & & & \\
\hline My work provides me with brighter future. & & .769 & & & & \\
\hline $\begin{array}{l}\text { My work provides opportunities for me to move } \\
\text { forward. }\end{array}$ & & .750 & & & & \\
\hline $\begin{array}{l}\text { The company provides sufficient rewards for } \\
\text { outstanding performance. }\end{array}$ & & & .780 & & & \\
\hline $\begin{array}{l}\text { The recognition I received differentiates me from } \\
\text { the other employees. }\end{array}$ & & & .765 & & & \\
\hline $\begin{array}{l}\text { The rewards provided by the company are } \\
\text { irresistible. }\end{array}$ & & & .758 & & & \\
\hline $\begin{array}{l}\text { The rewards provided by the company are worth } \\
\text { pursuing. }\end{array}$ & & & .685 & & & \\
\hline $\begin{array}{l}\text { I received recognition from the supervisor for } \\
\text { excellent performance. }\end{array}$ & & & .675 & & & \\
\hline Doing my job makes me a better person. & & & & .740 & & \\
\hline My job allows me to improve myself. & & & & .709 & & \\
\hline $\begin{array}{l}\text { My job allows me to equip myself with new } \\
\text { knowledge }\end{array}$ & & & & .672 & & \\
\hline $\begin{array}{l}\text { My skills improve from time to time when doing my } \\
\text { job. }\end{array}$ & & & & .666 & & \\
\hline I receive adequate on-the-job training. & & & & .565 & & \\
\hline $\begin{array}{l}\text { I have the required resources for the achievement } \\
\text { of the work goals. }\end{array}$ & & & & & .747 & \\
\hline $\begin{array}{l}\text { I have the capability to achieve the performance } \\
\text { target. }\end{array}$ & & & & & .704 & \\
\hline $\begin{array}{l}\text { I develop strategies to ensure the achievement of } \\
\text { the work goals. }\end{array}$ & & & & & .703 & \\
\hline $\begin{array}{l}\text { I have the support required to ensure the } \\
\text { achievement of the performance target. }\end{array}$ & & & & & .687 & \\
\hline I set realistic performance target for my work. & & & & & .512 & \\
\hline I have all the necessary tools to do my job well. & & & & & & .770 \\
\hline
\end{tabular}




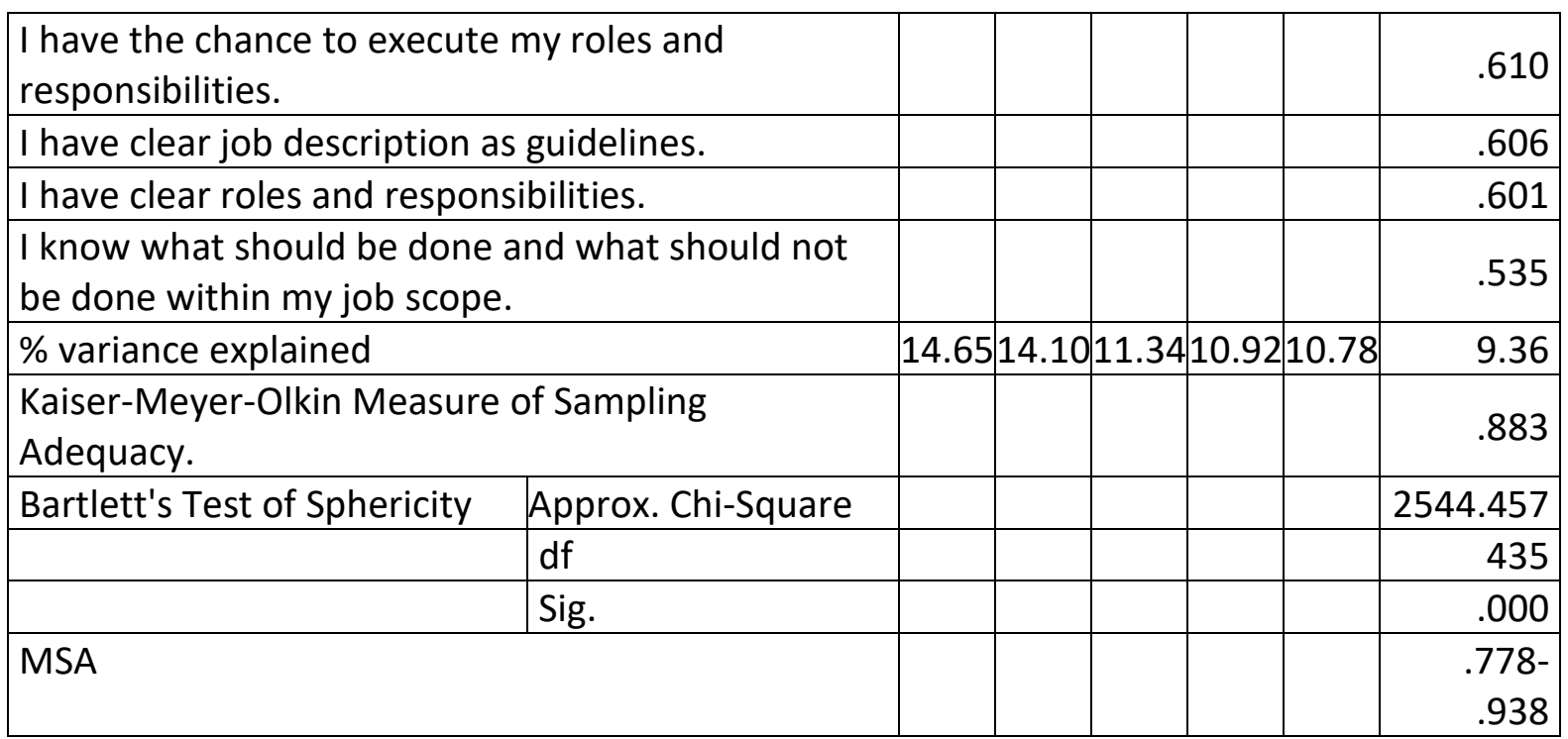

Extraction Method: Principal Component Analysis.

Rotation Method: Varimax with Kaiser Normalization.

A principle component factor analysis with varimax rotation was also used to examine the factor structure for the independent variables. Five items for each factor were developed and tested. The KMO value of .883 is good to indicate the suitability of factor analysis to be conducted. The MSA values range between .778 and .938 showing that the items were suitable to be used to measure each construct. The results of factor analysis indicate the existence of six factors to represent the independent variables. The first component has five items related to the work itself with loadings in the range between .694 and .790 . The name of this component is retained as the work itself. The second component contains five items measuring advancement with loadings ranging from .750 to .835 . The name of the factor is retained as advancement.

The third component reflects items assessing recognition. The factor loadings are sufficient ranging from .675 to .780 . Therefore, the name recognition is confirmed. The fourth factor refers to growth that contains items assessing respondents' growth potential. The factor loadings are adequate which range from .565 to .740 . The fifth factor has items measuring job achievement with sufficient factor loadings that range from .512 to .747 . The sixth factor has five items representing job responsibility. The factor loadings are adequate with values ranging from .535 to .770 . All the 30 items formed six factors that are used for the subsequent analyses. None of the items was deleted either due to high cross-loading or loading incorrectly under different components. 
Table 4: Result Correlation Analysis

\begin{tabular}{|l|l|r|c|c|c|c|c|c|c|c|}
\hline No & Variables & Mean & SD & 1 & 2 & 3 & 4 & 5 & 6 & 7 \\
\hline 1 & The work itself & 4.13 & .54 & $(.906)$ & & & & & & \\
\hline 2 & Advancement & 3.80 & .66 & $.556^{* *}$ & $(.941)$ & & & & & \\
\hline 3 & Recognition & 3.50 & .57 & $.344^{* *}$ & $.553^{* *}$ & $(.851)$ & & & & \\
\hline 4 & Growth & 4.04 & .59 & $.693^{* *}$ & $.625^{* *}$ & $.452^{* *}$ & $(.890)$ & & & \\
\hline 5 & Achievement & 3.97 & .51 & $.589^{* *}$ & $.464^{* *}$ & $.387^{* *}$ & $.608^{* *}$ & $(.825)$ & & \\
\hline 6 & Responsibility & 3.99 & .51 & $.644^{* *}$ & $.518^{* *}$ & $.390^{* *}$ & $.649^{* *}$ & $.604^{* *}$ & $(.835)$ & \\
\hline 7 & Intrinsic Motivation & 3.80 & .55 & $.477^{* *}$ & $.544^{* *}$ & $.484^{* *}$ & $.399^{* *}$ & $.546^{* *}$ & $.457^{* *}$ & $(.811)$ \\
\hline
\end{tabular}

Notes: ${ }^{* *}$. Correlation is significant at the 0.01 level (1-tailed); $\mathrm{N}=113$; Cronbach's alphas are in the parentheses along the diagonal

The above table (Table 4) contains three important information; means and standard deviations of all variables, Cronbach's alphas, and correlation coefficients. The mean and standard deviation of the variables indicate that the scores for the variables range from moderate to high, indicating that the respondents are in agreement with all the variables in study. The values of Cronbach's alphas are in the range of .811 to .906 , indicating that the items measuring each construct are highly reliable.

A correlation analysis was performed to examine the convergent/divergent and concurrent validity of the factors.Among the independent variables, the lowest $r$ value is for the relationship between the work itself and recognition $(r=.344, p<.001)$ and the highest $r$ value is between the work itself and growth $(r=.693, p<.001)$. The significant relationships between variables indicate convergent validity. For the relationship between the independent variables and the dependent variable (testing the concurrent validity), the lowest correlation is observed between growth and intrinsic motivation $(r=.399, p<.001)$ and the highest correlation is confirmed between achievement and intrinsic motivation ( $r=.546, p<.001)$. Therefore, the potential relationships between the independent variables and the dependent variable are confirmed. 
INTERNATIONAL JOURNAL OF ACADEMIC RESEARCH IN BUSINESS AND SOCIAL SCIENCES Vol. 11, No. 11, 2021, E-ISSN: 2222-6990 @ 2021 HRMARS

Table 5: Result of Multiple Regression Analysis

\begin{tabular}{|l|c|c|c|}
\hline Variables & \multicolumn{3}{|c|}{ Standardized Beta Coefficients } \\
\hline The Work Itself & Model 1 & Model 2 & Model 3 \\
\hline Advancement & .171 & .186 & .160 \\
\hline Recognition & $.242^{* *}$ & $.234^{* *}$ & .209 \\
\hline Growth & $.211^{*}$ & $.208^{*}$ & .209 \\
\hline Achievement & $-.230^{*}$ & -.213 & -.228 \\
\hline Responsibility & $.362^{* *}$ & $.352^{* *}$ & $.502^{* *}$ \\
\hline Moderator & .076 & .061 & -.004 \\
\hline Organization type & & & -.097 \\
\hline Interaction terms & & .056 & .055 \\
\hline WorkXpublic & & & .058 \\
\hline AdvancementXpublic & & & .015 \\
\hline RecognitionXpublic & & & .114 \\
\hline GrowthXpublic & & & $-.494^{*}$ \\
\hline AchievementXpublic & & & .200 \\
\hline ResponsibilityXpublic & & .682 & .703 \\
\hline R & .679 & .465 & .494 \\
\hline $\mathrm{R}^{2}$ & .462 & .430 & .427 \\
\hline Adjusted R & .431 & .411 & .923 \\
\hline F change & 15.153 & & .482 \\
\hline Sig F change & .000 & & 1.890 \\
\hline Durbin Watson & & & \\
\hline
\end{tabular}

Notes: ${ }^{*}$ significant at the 0.05 level; ${ }^{* *}$ significant at the 0.01 level

A multiple regression analysis was performed to examine the factors that contribute to explaining motivation among the employees in service organizations (the first step of the 3step moderated multiple regression analysis). Testing the direct influence between the independent variables and motivation, the $\mathrm{R}^{2}$ of .462 indicates that $46.2 \%$ of the variance in motivation is explained by the independent variables. The model is significant $(F(6,106)=15.153)$. Durbin Watson value of 1.890 indicates no auto correlation issue in the regression model. Looking at the contribution of each independent variable in explaining motivation, four out of six factors are significant. They are advancement $(\beta=.242, p<0.01)$, recognition $(\beta=.211, p<0.05)$, growth $(\beta=-.230, p<0.05)$, and achievement $(\beta=.352, p<0.01)$. The non-significant factors are the work itself $(\beta=.171, p>0.05)$ and responsibility $(\beta=.076$, $p>0.05)$.

Types of the organization was included in the second step of the moderated multiple regression analysis to examine the role of the variable to affect the relationship. The results indicate that the inclusion of the factors does not influence the relationship. The $R^{2}$ value of .465 shows a non-significant increase in the explanation of variance $(F(7,105)=13.046)$. Therefore, it can be concluded that the inclusion of the moderating variable does not significantly change the influence of the independent variables on the dependent variable. The test was continued with the inclusion of the interaction terms between types of 
organization as the moderating variable and the independent variables in order to examine their effects on motivation. The $\mathrm{R}^{2}$ increases to .494 but is not sufficient to contribute significantly to affect the relationship $(F(13,99)=7.420)$. therefore, it can confidently be concluded that types of organization (public or private organization) do not moderate the relationship between motivation factors and motivation level of employees.

\section{Discussion}

The purpose of this paper is to investigate the influence of intrinsic motivation factors on the motivation level of employees working in public and private service organizations. The results of multiple regression analysis indicate the significant influence of four out of six intrinsic motivation factors on the employee motivation level. The significant factors are advancement, recognition, growth, and achievement. But growth has a negative relationship with motivation.

Advancement is related to career advancement or promotion. The job that has provided the opportunity for career advancement to employees will make them feel motivated and most probably will make them work harder to help the organization succeed. The findings are consistent with those of previous studies in this aspect (Asaari, et al., 2019; Do, 2020; Haryono, et al., 2020; Ogini. 2020). Recognition is also significant to influence motivation. Employees who received recognition from their superiors and peers based on the work performance are motivated to perform their duties. The findings are also in line with the previous studies (Assari, et al., 2019; Grant, et al., 2018; Rahim et al., 2017).

Growth is also significant to influence motivation but in a negative fashion. High growth potential derived from the job will demotivate the employees. The findings are inconsistent with previous studies (Kenku et al., 2019; Linn, 2019; Mani \& Mishra, 2020; Rhew, et al., 2018). The most plausible reason is that growth is a long term objective and normally will not be the focus of the employees. Most employees and employers will concentrate their attention to achieve the current or yearly goals and they do not consider growth as their main concern. Those who consider growth as the main target will sometimes fail to consider the current work requirements and this will lower their motivation level.

Another significant predictor of employee motivation is achievement. Job achievement provides an immediate spiritual encouragement to employees to move forward and working harder. It signals a "job well done" message to employees so that they will feel proud of their current work performance. The findings provide support to those of the previous studies such as (Asaari et al., 2019; Maharani, Agussalim and Yanti, 2021; Mohamed and Puteh, 2018; and Werdhiastutie, et al., 2020). The non-significant factors are the work itself and responsibility. The work itself and responsibilities are something that the employees have to shoulder regardless whether they like it or not. These factors do not trigger their motivation as they have to follow their job description closely without any argument.

Types of organization did not significantly moderate the relationship between motivation factors and employees' intrinsic motivation as expected. Although the scores for the independent variables among the public organization employees are higher than those in the private organizations, the evidence is insufficient to support it. The most plausible reason for the finding is that, similar to personality traits and self-efficacy, intrinsic motivation factors 
are the inner drives that motivate employees from within (Su et al., 2021). These factors have been developed and nurtured over a period of time in individuals and become their common traits. The motivated feeling resulting from performing the job itself, regardless whether the employees are working in public or private organizations, is important to motivate them to work harder to achieve the organization goals.

\section{Conclusion}

Service employees deal with challenging jobs as the work itself is subjective since there is no specific measurable indicator to determine its success. Due to the different nature of work that the service employees are performing, the present study was undertaken to determine factors that contribute to intrinsic motivation of employees working in public and private service organizations. Using 113 data collected from online means, the results of a multiple regression analysis indicate that out of six intrinsic motivation factors, four factors are significant to motivate service employees. The significant factors are advancement, recognition, growth, and achievement while the non-significant factors are the work itself and responsibility. However, the study failed to prove that types of organization moderate the relationship between the predictor variables and the outcome variable. It can be concluded that types of organizations did not affect the relationship between instrinsic motivation factors and employee job satisfaction. Regardless of the organization types, the aspects of advancement, recognition, growth and achievement should be highly considered by the top management in order to make their employees satisfied with their job. Satisfied employees will exert considerable effort to ensure their organization success. Furthermore, it is also recommended that future studies should be conducted to further validate the research instrument used and verify the findings of the study using greater samples from different geographical contexts.

\section{References}

Abdelmotaleb, M. (2020). The moderating and mediating role of public service motivation between organization's social responsibility and employee engagement: evidence from Egyptian public hospitals. International Review of Public Administration, 25(3), 207-223.

Amzat, I. H., Don, Y., Fauzee, S. O., Hussin, F., \& Raman, A. (2017). Determining motivators and hygiene factors among excellent teachers in Malaysia. International Journal of Educational Management, 31(2), 78-97.

Asaari, M. H. A. H., Desa, N. M., \& Subramaniam, L. (2019). Influence of salary, promotion, and recognition toward work motivation among government trade agency employees. International Journal of Business and Management, 14(4), 48-59.

Atkinson, J. W. (1964). Introduction to motivation. Princeton, NJ: Van Nostrand.

Christensen, R. K., Paarlberg, L., \& Perry, J. L. (2017). Public service motivation research: Lessons for practice. Public Administration Review, 77(4), 529-542.

Do, Q. H. (2020). Factors affecting job motivation among faculty members: Evidence from Vietnamese public universities. The Journal of Asian Finance, Economics, and Business, 7(9), 603-611.

Grant, C., Nawal, D., Guntur, S. M., Kumar, M., Chaudhuri, I., Galavotti, C., ... \& Alam, M. A. (2018). 'We pledge to improve the health of our entire community': Improving health worker motivation and performance in Bihar, India through teamwork, recognition, and non-financial incentives. PloS one, 13(8), e0203265. 
Haryono, S., Supardi, S., \& Udin, U. (2020). The effect of training and job promotion on work motivation and its implications on job performance: Evidence from Indonesia. Management Science Letters, 10(9), 2107-2112.

Herzberg, F., Mausner, B., \& Snydermann B. (1959). The motivation to work. New York: Wiley. Iliyasu, R., \& Etikan, I. (2021). Comparison of quota sampling and stratified random sampling. Biom. Biostat. Int. J. Rev, 10, 24-27.

Jaakkola, E., Meiren, T., Witell, L., Edvardsson, B., Schäfer, A., Reynoso, J., ... \& Weitlaner, D. (2017). Does one size fit all? New service development across different types of services. Journal of Service Management, 28(2), 329-347.

Kenku, A. A., Tanimola, F. A., \& Ishola, A. A. (2019). Need for achievement, personal growth initiative as co-variates of work motivation. The Journal of Positive Psychology and Counselling, 3(2), 136-145.

Larivière, B., Bowen, D., Andreassen, T. W., Kunz, W., Sirianni, N. J., Voss, C., ... \& De Keyser, A. (2017). "Service Encounter 2.0": An investigation into the roles of technology, employees and customers. Journal of Business Research, 79, 238-246.

Linh, N. H. N. (2019). Factors affecting work motivation of civil servants in Thua Thien Hue provincial people's committee. Hue University Journal of Science: Economics and Development, 128(5C), 81-95.

Liu, H., Fan, J., Fu, Y., \& Liu, F. (2018). Intrinsic motivation as a mediator of the relationship between organizational support and quantitative workload and work-related fatigue. Human Factors and Ergonomics in Manufacturing \& Service Industries, 28(3), 154-162.

Magga, H. A., Mas'ud, M., Gani, A., \& Hasbi, A. M. (2019). Effect of leadership style, job promotion, and organizational work culture on motivation and civil servant performance in South Sulawesi. International Journal of Innovative Science and Research Technology, 4(10), 324-330.

Maharani, S., Agussalim, M., \& Yanti, N. (2021). Effect of work satisfaction on work achievement through motivation. Matua Jurnal, 3(2), 235-248.

Mani, S., \& Mishra, M. (2020). Non-monetary levers to enhance employee engagement in organizations-"GREAT" model of motivation during the Covid-19 crisis. Strategic HR Review, 19(4), 171-175.

McCarthy, D., Wei, P., Homberg, F., \& Tabvuma, V. (2019). Public service motivation in the Chinese public and private sectors. In Evidence-based HRM: a Global Forum for Empirical Scholarship. Emerald Publishing Limited.

Mohamed, N. N. B., \& Puteh, H. F. B. H. (2018). Generation Y in Malaysian GLCs: Relationship between Herzberg's motivation factors and job commitment. Journal of Administrative Science, 15(1), 1-13.

Ogini, J. A. (2020). Job promotion and employee commitment of public hospitals in Rivers State, Nigeria. International Journal of Economics and Business Management, 6(1), 10 22.

Omar, M. K., Rashid, A. M., \& Puad, M. H. M. (2018). Examining job satisfaction factors toward retaining Malaysian TVET instructors in the teaching profession. International Journal of Engineering \& Technology, 7(2.10), 44-49.

Osborne, S. P. (2018). From public service-dominant logic to public service logic: Are public service organizations capable of co-production and value co-creation?. Public Management Review, 20(2), 225-231. 
Rahim, I. F. A., Wahab, R. A., \& Munir, Z. A. (2017). Reward and recognition with employee Motivation: A study on a Malaysian private sector. Advanced Science Letters, 23(8), 7338-7341.

Ravesangar, K., \& Muthuveloo, R. (2019). The influence of intrinsic and extrinsic motivating factors on work performance at banking sectors in Malaysia: The mediator role of psychological ownership. e-Jurnal Penyelidikan dan Inovasi, 6(2), 51-70.

Rhew, E., Piro, J. S., Goolkasian, P., \& Cosentino, P. (2018). The effects of a growth mindset on self-efficacy and motivation. Cogent Education, 5(1), 1492337.

Rodrigues, A. F. (2018). Decent work, work motivation and orientation to happiness: A profile analysis (Doctoral dissertation, Universidade de Coimbra).

Silvestro, R., Fitzgerald, L., Johnston, R., \& Voss, C. (1992). Towards a classification of service processes. International Journal of Service Industry Management, 3(3), 399-450.

Su, W., Lyu, B., \& London, M. (2021). Relationships between developmental feedback, intrinsic motivation, and creative personality and performance. Psihologija, (00), 3737.

Van Hooff, M. L., \& Van Hooft, E. A. (2017). Boredom at work: Towards a dynamic spillover model of need satisfaction, work motivation, and work-related boredom. European Journal of Work and Organizational Psychology, 26(1), 133-148.

Van Tuin, L., Schaufeli, W. B., Van den Broeck, A., \& Van Rhenen, W. (2020). A Corporate purpose as an antecedent to employee motivation and work engagement. Frontiers in Psychology, 11, 1-12.

Werdhiastutie, A., Suhariadi, F., \& Partiwi, S. G. (2020). Achievement motivation as antecedents of quality improvement of organizational human resources. Budapest International Research and Critics Institute-Journal (BIRCI-Journal) Volume, 3, 747-752. 